\begin{tabular}{|l|c|}
\hline \multicolumn{2}{|c|}{ Toppan Best-set Premedia Limited } \\
\hline Journal Code: POST & Proofreader: Mony \\
\hline Article No: POST12167 & Delivery date: 15 Sep 2014 \\
\hline Page Extent: 18 & \\
\hline
\end{tabular}

\title{
Methodological Nationalism, Migration and Political Theory
}

\begin{abstract}
Alex Sager
Portland State University

The political theory of migration has largely occurred within a paradigm of methodological nationalism and this has led to the neglect of morally salient agents and causes. This article draws on research from the social sciences on the transnationalism, globalization and migration systems theory to show how methodological nationalist assumptions have affected the views of political theorists on membership, culture and distributive justice. In particular, it is contended that methodological nationalism has prevented political theorists of migration from addressing the roles of non-state agents and of transnational economic, social and political structures. These agents and structures contribute to the asymmetrical distribution of goods and opportunities and thus have important implications for debates about migration and distributive justice.
\end{abstract}

Keywords: political theory; methodological nationalism; migration; distributive justice; culture

Political theorists of migration have largely operated within a conceptual scheme that analyzes migration from the perspective of nation-building or within an international framework of autonomous, sovereign states. For the most part, they have not engaged powerful criticisms of 'methodological nationalism' in the social sciences. As a consequence, they ignore how morally salient transnational networks, associations and organizations and global social and economic structures shape migration. This leads to the neglect of questions of agency and structure, and omits causal relations that entail moral responsibilities. Insights from transnational and global studies of migration reveal neglected or misunderstood moral policy dimensions and open new questions for political theorists.

This article explains how methodological nationalism distorts research on migration in the social sciences and leads to descriptive and explanatory inadequacy. It illustrates how prominent positions on migration and political theory depend on a methodological nationalist perspective. The impact of methodological nationalism on normative work on citizenship, membership, culture and distributive justice is discussed. Though some political theorists have begun to recognize the importance of transnationalism for normative work on issues of citizenship, membership and culture, there is little cognizance of how studies of migration systems and transnationalism affect distributive justice. The article addresses possible objections from political theorists about the relevance of empirical work on migration and uses the North American migration system to demonstrate how insights from global and transnational approaches to migration better inform normative discussion of migration and distributive justice. 


\section{The Critique of Methodological Nationalism}

Methodological nationalism is a stance in the social sciences that unjustifiably presupposes the nation-state, uncritically treats it as the natural form of social organization and/or reifies it (Amelina et al., 2012; Beck, 2000; Chernilo, 2006). The nation-state is assumed to completely control geographical space and is treated as synonymous with society. Methodological nationalism leads to a fundamental misunderstanding of the nature of social reality by failing to recognize transnational, sub- and supra-state organizations, and by not taking into account how nations are situated in and constituted by local, transnational and global forces. Critics of methodological nationalism do not deny the continued importance of nation-states in shaping migration flows (Glick Schiller, 2012, p. 41), but rather invite a more careful consideration of nature and role. Nation-states themselves are shaped by global and transnational forces that limit their ability to decide policy and control migration flows.

Andreas Wimmer and Nina Glick Schiller identify three mutually reinforcing variants of methodological nationalism in migration studies: ignorance, naturalization and territorial limitation (Wimmer and Glick Schiller, 2002; 2003; Glick Schiller, 2010). Ignorance occurs when 'nation-state- serves as an invisible background for theorists: theorists presuppose the nation-state without realizing how this presupposition affects their theorizing. They ignore how ideas and categories such as 'citizen', 'immigrant', 'temporary migrant' and 'tourist' are shaped by nationalist background assumptions. Theorists unaware of their nationalist presuppositions frequently compare immigrant and native-born populations without reflecting on the internal heterogeneity of these groups or the usefulness of these categories (Huntington, 2005).

A second variant of methodological nationalism naturalizes the nation-state: theorists acknowledge the nation-state, but treat it as unproblematic and fail to examine it as a methodological posit. Flows of goods, capital and people are typically seen within an international framework. The world is divided into separate, sovereign nation-states and little consideration is given to why the nation-state enjoys its hegemonic status (Wimmer and Glick Schiller, 2002, p. 304). Nation-building projects are legitimized, often at the price of exaggerating internal cultural homogeneity and suppressing processes of internal displacement, racializing portions of the population, and otherwise obliterating or marginalizing diversity (Anderson, 2006). Studies of the economic effects of migration on native workers presuppose that the nation-state is the unit of analysis (Borjas, 2001). Research on the effects of skilled migration and the fear that this causes 'brain drain' derive their legitimacy from their acceptance of nation-states' self-definitions (Kapur and McHale, 2005).

Finally, territorial limitation occurs when social scientists operate solely within the boundaries of the state and 'thus remove trans-border connections and processes from the picture' (Wimmer and Glick Schiller, 2002, p. 307). Demographic and economic data collected by states reinforce state definitions of boundaries and membership (Smith, 1983, p. 26). Immigration is studied without attention to emigration or acknowledgement of internal migration, and official statistics fail to register circular migration. Territorial limitation also allows studies of multiculturalism to take place solely within the context of receiving 
societies and for immigrants to be unreflectively categorized according to their integration or assimilation to dominant groups defined by nation-building projects (Bloemraad et al., 2008; Joppke and Morawska, 2002).

Theorists of globalization and transnationalism have shown how ontological shifts in the global economy, politics, culture and society require the rethinking of basic categories (Robinson, 2001). Space-time compression has enabled the creation of transnational spaces that overlap, undermine and transform sovereign states. International travel and telecommunication have allowed migrants and communities abroad to more easily maintain connections and to join people in economic, cultural and religious networks (Levitt and Schiller, 2006).

The rejection of methodological nationalism has precedents in Marxist approaches and world systems theory (Wallerstein, 1974; Wolf, 1982), as well in Portes and Bach's investigations of Cuban and Mexican migration (Portes and Bach, 1985). Since the early 1990s, social scientists studying migration have increasingly accepted the need to incorporate the insights of transnationalism and the criticisms of methodological nationalism (Levitt and Jaworsky, 2007). In their influential Nations Unbound, Linda Basch, Nina Glick Schiller and Cristina Szanton Blanc described how their anthropological research on migrants from Grenada and St Vincent (Basch), Haiti (Glick Schiller) and the Philippines (Szanton Blanc) confronted the limitations of an analytic framework limited to 'immigrants' who come to stay and 'migrants' who reside for a period before returning to their homes (Basch et al., 1994). This framework with its methodological categories such as 'ethnic group,' 'race' and 'nation' did not capture how transmigrants maintain ongoing relationships with two or more homes. Instead, they conceived transnational migration as a process in which migrants build social fields that reconfigure space, culture and identity alongside and in reaction to nation-building projects and global capitalism.

Transnational migrations have social, cultural, political and economic dimensions that inform each other (Levitt and Jaworsky, 2007). Social remittances spread new ideas, practices and norms between geographical regions (Levitt, 1998). Migrants maintain transnational connections with families, and migration itself changes family arrangements when one or both parents migrate. Most strikingly, gender roles and hierarchies structure women's migration which in turn modifies gender roles for women and men (Salazar Parreñas, 2008). Transnational migration also contributes to the transformation of cultural practices in art, music, literature, fashion.

States have become increasingly tolerant of people retaining the citizenship from other countries and many people hold dual or multiple citizenships (Bauböck, 2011). Though the degree of political transnationalism can be overstated (Portes, 2003), migrants also engage in political activity, including voting from abroad (IDEA, 2005), political activism and nation-building. Political transnationalism encompasses activities such as voting or supporting political parties in national politics as well as regional (including city) politics. More broadly, it 'affects collective identities and conceptions of citizenship among the native populations in both receiving and sending societies' (Bauböck, 2003, p. 720).

Since the major focus of this article is on distributive justice, the economic dimensions of transnationalism are particularly important. Migration and development interact in complex ways. One type of economic transnationalism is remittances. The World Bank 
estimates US $\$ 410$ billion in officially recorded remittances was sent to developing countries in 2012 with unrecorded remittances thought to total perhaps US $\$ 1025$ billion. Migrants from China, India and the Philippines sent back approximately US $\$ 69$, US\$60 and US $\$ 24$ billion, respectively, in officially recorded remittances in 2011. Remittances made up shares of 47 and 31 per cent of gross domestic product for Tajikistan and Liberia, respectively, and over 20 per cent of the GDP for Haiti, Samoa, Nepal, Moldova, Lesotho and the Kyrgyz Republic. Families often use migration as a strategy to supplement income, maintaining long-term transnational ties to members abroad (Stark, 1991). Migrants sending remittances often do not fit into categories of sojourners or permanent residents who have severed ties from their countries of origin.

Migrants' economic contributions are not limited to remittances. They may also engage in transnational entrepreneurship in financial services, raw materials, goods and cultural products (Zhou, 2006). Migrants develop human, social and cultural capital which they 3 transmit to their countries of origin. Ethnic networks enable them to build technological bridges and to serve as intermediaries linking businesses around the globe. Migrants' contributions to their countries of origin also include the exchange of values, norms and ideas.

An account of the normatively relevant interactions between migration and development requires macro-level structural analysis. State-level policies and networks are situated within a global capitalist system that helps explain some migration flows. A basic feature of capitalist economies is creative destruction, where innovation, often originating from other geographical regions, transforms economies. The incorporation of regions into the global market drives migration (Sassen, 1988). Urbanization and the destruction of peasant economies lead to internal migration to urban areas, often as a preliminary step toward relocating abroad. Migration flows follow foreign investment, resource extraction and multinational firms engaged in producing goods for exportation (Massey et al., 1998, pp. 34-41).

Economic globalization, coupled with rigid border controls enforced by states, creates an asymmetrical division of labor. Global cities need migrants due to structural changes that have created markets for high-skilled, well-paid workers and for low-wage workers (e.g. domestic workers) often drawn from abroad. Domestic economies are bifurcated with primary sectors providing permanent, relatively high wage jobs and a secondary sector characterized by precarious, dirty, dangerous and demeaning jobs filled by migrants (Piore, 1980). This bifurcation can only be understood against a background of a readily accessible, transnational labor force with foreign workers who are 'wanted but not welcome' (Zolberg, 1987).

The identification of causes of migration flows from specific geographical sites demands an understanding of how connections around the world in technologically reconfigured space have reshaped economic, social and political institutions. People migrate to places where other people from their community have established themselves. They make use of migration networks that provide them with resources (e.g. a place to stay and work upon arrival) and information. Networks provide the scaffolding for transnational strategies in which individuals and families make use of cross-border connections to redress spatially distributed inequalities. Saskia Sassen (2002) dubs these connections 'survival circuits' 
where migration remittances sustain individuals and households battered by the world economy.

Migration networks often have their origins in past migrations and in government policies (e.g. labor recruitment programs) that attract a significant number of people from sending areas. Policies allowing for family reunification contribute to chain migration, furthering the distributive effects of networks. Networks may develop into migration systems, a migration industry of recruiters, nongovernmental organizations, smugglers and others sustain migration flows (Gammeltoft-Hansen and Nyberg Sorensen, 2012; Hernández León, 2012a). The outsourcing of enforcement, detention and deportation to private security companies has increasingly allowed powerful private actors, including banks, firms and military suppliers, to shape borders and border controls (Lemberg-Pedersen, 2012). Migration systems contain complex feedback mechanisms that 4 span and modify social, cultural and economic relations and opportunities in countries of origin and of destination. These mechanisms are largely invisible to a perspective obscured by methodological nationalism.

\section{Political Theory and Methodological Nationalism}

Political theorists of migration have for the most part not engaged the social scientific literature on methodological nationalism. Despite their theoretical differences, political theorists of migration are largely committed to a social ontology that presupposes the nation-state as the basic agent and unit of analysis. They assume an international system of sovereign states with limited consideration of other structures and actors. People belong to only one state and are classified either as natives or foreigners. States are the primary actors requiring moral scrutiny, and the regulation of people seeking to move across their borders is the central topic of investigation. Migration for economic opportunities, cultural choice or family reasons goes unremarked if it takes place within the borders of the state, but immediately raises moral questions when it involves crossing an international border. The container view of the nation-state leads political theorists to ignore the perhaps 740 million internal migrants and to automatically problematize the presence of 214 million international migrants (King et al., 2008; UNDP, 2009). Political theorists follow state policy makers in distinguishing the 26.8 million internally displaced people in 2011 fleeing violence, persecution or natural disasters from the 10.4 million refugees who have crossed an international border for similar reasons (Lister, 2012).

Methodological nationalism is accepted by political theorists with seemingly disparate views. Communitarians and liberal nationalists tend to naturalize the nation-state by presupposing homogenous cultures bounded within it and by too quickly assuming that the scope of distributive justice ends at state borders. Cosmopolitans, libertarians and utilitarians often deny the moral relevance of borders and commit the error of ignorance by failing to analyze their nature, effects and complexities.

In surveying how political theory succumbs to methodological nationalism, I focus in this article on membership and distributive justice. First, membership is defined by state borders so that multiple citizenship and transnational memberships are ignored or problematized. Similarly, the definition of culture follows nation-building projects. Some progress has been made on questions of membership in work on the scope of the demos

(C) 2014 The Author. Political Studies (C) 2014 Political Studies Association POLITICAL STUDIES: 2014 
and on culture, but the implications of this work have not been fully recognized. Second, discussions of distributive justice treat nations as discrete and autonomous containers with sedentariness as the default position. I argue that the implications of migration systems theory and transnationalism are highly significant for distributive justice, revealing underexplored moral dimensions and new avenues of normative research.

\section{Membership and Culture}

Methodological nationalism underlies a set of assumptions about membership and culture that mirror and legitimize nation-building projects. First, many political theorists uncritically structure their theories using a model in which each person belongs exclusively to a single society or state. This leads many theorists to continue to ground their theories in problematic assumptions about membership. For example, David Miller's views on migration emerge from his closely connected views on territorial-based national selfdetermination, citizenship and democracy. On Miller's account, 'nations are communities whose members see themselves as having obligations of mutual aid that are more extensive than the aid they owe human beings generally' (Miller, 2007, p. 131) and, where possible, nations enjoy rights over territories they have adapted to and shaped in turn. This is necessary for Miller since he holds that the state cannot function 'in the absence of well-defined geographical limits to its authority' (Miller, 2007, p. 214). Though he grants that states that claim 'legitimate authority over a territory must also take reasonable steps to protect the human rights of those whose position is worsened by the boundaries it defends' (Miller, 2007, p. 221), he insists that migration policy ought to be decided by the society's general goals that 'reflect existing national values' and 'ideally set a continuing process of democratic debate' (Miller, 2007, p. 222). Democratic debate is supported by a national culture which Miller (2000) has been at pains to defend against both cosmopolitan and subnational accounts of democracy. His philosophy of migration has at its core the assumption that the members of relevant societies and political communities cluster in nations enjoying control over a territory, ignoring not only the complexities of transnational and multinational membership, but also ways in which economic and environmental values are sustained by cross-border institutions and systems.

In a similar vein, Christopher Heath Wellman has argued that that people in legitimate states have a right to political self-determination partly constituted by a principle of freedom of association (Wellman and Cole, 2011). This principle includes the right to not associate with some people, and this right outweighs any claims that migrants have to entry. Critics of Wellman's position have questioned the cogency of his analysis of freedom of association (Blake, 2012a; Fine, 2010), but have largely neglected the possibility that the relevant associations are not in fact contained within the boundaries of the nation-state. This one-person one-state model has no place for dual and multiple citizenships and ignores external voting rights and transnational political activity.

Second, debates about integration, assimilation and culture frequently presuppose a unified, background culture and immigrants are frequently understood to pose unique economic, cultural and security risks. Political theory mirrors much empirical literature in seeing migrants to be in need of integration or assimilation (Carens, 2013; Miller, 2008). This occurs in the work of political theorists who see culture as a central consideration for 
migration policy and minority rights. Michael Walzer (1983, p. 38) holds that border controls are essential to preserve territorial bounded 'communities of character', whereas David Miller (2005) argues for the need to control the volume of immigration to allow for cultural continuity. Will Kymlicka (2001) sees migration restrictions as necessary to protect 'societal cultures', and Joseph Carens qualifies his arguments for open borders with a 'cultural caveat' under which

[s]tates have the right to restrict migration only if they can show, on the basis of evidence in an impartial (but internal) forum, that further migration would endanger the survival of the national language and culture, and they may exercise this right of restriction only so long as and to the extent that the danger persists (Carens, 2013, p. 286).

Brian Barry (2002, p. 72) also argues at length that 'it is an appropriate objective in a liberal democratic state to facilitate the state of affairs in which all immigrants - or at least their descendants - become assimilated to the national identity of the country in which they have settled'.

Finally, the state-centered model of methodological nationalism plays a role in the work of political theorists who ask about the permissibility of denying rights to temporary migrants that are enjoyed by citizens (Bell and Piper, 2005; Carens, 2013). Much of this 5 debate asks whether temporary membership and the exploitation that results from temporary labor programs are compatible with liberal norms of equal respect or whether temporary workers must be guaranteed a path to full membership (Attas, 2000; Lenard and Straehle, 2011). Little consideration is given to the possibility that the permanent/ temporary dichotomy is in fact misleading and that migrants may simultaneously belong to more than one community.

Though the container theory of society continues to inform many political theorists' assumptions about membership and culture, its limitations are increasingly apparent. Cosmopolitan theorists have questioned communitarian and nationalist accounts of identity and culture and emphasized how cross-border processes constitute who we are (Waldron, 1992). Patti Lenard (2010) has drawn attention to how the transnational dimensions of culture may generate claims to membership. Recent work on the scope of the demos has alerted political theorists to challenges of multiple and transnational memberships and the need for a normative account to ground a right to membership and the rights it entails (Bauböck, 2003; 2011; Owen, 2012). This literature moves the debate in a promising direction, but has yet to dispel most theorists' methodological nationalist prejudices about membership and culture.

\section{Distributive Justice}

Political theorists are less aware of how methodological nationalism impinges on their views of migration and distributive justice. Normative migration theorists commonly frame the moral dilemmas of migration policy with the observation that place of birth has a defining, but morally arbitrary influence on people's life chances. In these debates, the legitimacy of coercive exclusion of much of the world's population from regions with better opportunities and higher wages is a central topic in determining the justice of migration policy. Theorists differ widely on the implications of global inequalities for

(C) 2014 The Author. Political Studies (C) 2014 Political Studies Association POLITICAL STUDIES: 2014 
migration, but they largely share methodological nationalist assumptions. In particular, they treat states as isolated containers that generate opportunities independent of cross-border or global forces and see individuals as essentially sedentary.

This gives rise to three prominent views in political theory: (1) distributive justice is seen as occurring between discrete, non-overlapping geographical units that generate opportunities in isolation of supranational and international actors, policies and phenomena; (2) international migration is automatically treated as puzzling and potentially problematic while sedentariness remains an untheorized default position; and (3) the moral implications of international migration, particularly the migration of skilled workers, are built on the presupposition that each individual belongs to one state.

First, methodological nationalism affects the political theory of migration by framing distributive justice in an international framework that treats each state as an autonomous monad. Opportunities are located in isolated containers defined by the geographical boundaries of the nation-state. Little attention is given to how opportunities are constituted through relationships between territories (e.g. due to trade or capital flows) or to classifications of opportunities that cross national lines (e.g. based on social class or gender).

This container view of society enables Lea Ypi (2008) to treat borders as the explanans of spatially differentiated opportunities and to take for granted the idea that each nationstate bounds a moral community or society. She argues that there are distinct considerations of 'justice in immigration' (addressing the members of proposed host societies) and considerations of 'justice in emigration' (addressing the members of sending societies) and that they are fundamentally in conflict. Ypi grounds her arguments on claims about the costs of immigration to the worst off members of receiving societies and the costs of skilled migration to receiving countries (Ypi, 2008, pp. 400 and 402).

Operating with similar theoretical assumptions, Eric Cavallero (2006) treats the fact that opportunities are unevenly distributed across national borders as problematic. He analyzes the morality of migration according to the aggregate demand for entry to states. States with 'positive immigration pressure' (i.e. more people want to immigrate than emigrate) have to choose between admitting more foreigners and compensating other states with developmental aid. This methodological nationalism underlying this 'immigration-pressure model' allows Cavallero to ignore the interrelationship between migration and development, including the observation that effective developmental aid is likely to lead to more migration in the short run (De Haas, 2010). More generally, it misses powerful criticisms of how migration and development are bandied about in policy circles without attention to capitalist restructuration, transnational flows of labor and capital, asymmetrical power relations and migrant agency (Glick Schiller and Faist, 2010).

In another variation of the container theory of the nation-state, Ayelet Shachar's proposal for a 'birthright privilege levy' to redistribute the gains from birthright citizenship across borders presupposes bounded societies (Shachar, 2009). This diagnosis and solution assumes a world in which citizenship is invariably passed down from generation to generation along national lines and in which opportunities have overwhelmingly domestic origins. This overstates the rigidity of borders, assumes that states generate opportunities in isolation and understates inequalities internal to states. 
Finally, Ryan Pevnick (2011, p. 56) argues that publicly provided goods created by bounded political communities act as magnets pulling people from abroad. He holds that citizens' contributions to maintaining state institutions provide them with claim to ownership. This claim endows citizens with a right to self-determination over their collective property that entails a right to exclude foreigners who enjoy adequate opportunities in their countries of origins. Pevnick's methodological nationalism contributes to his assumption that citizens' efforts produce public goods without any substantial contribution from outside forces.

The second way methodological nationalism affects political theory is by treating international migration as an anomaly. Political theorists tend to see migration as a response to abnormal, adverse circumstances such as poverty or persecution and to insist that it would largely disappear as a serious moral subject if these circumstances were addressed (Rawls, 2002 ; p. 9; Walzer, 1983, p. 38). The assumption of sedentariness underlies the 6 common claim that people who lack adequate opportunities within their states to live decent lives have a right to migrate, but those who can access adequate bundles of goods within their national borders forfeit this right (Hidalgo, 2014; Miller, 2005, p. 196; Pevnick, 2011, p. 84). This assumption also contributes to the view that there is a trade-off between migration and development (Pogge, 2006) or that development aid can be offered in lieu of visas (Cavallero, 2006; Kymlicka, 2001, p. 271; Wellman and Cole, 2011, pp. 130-2).

Third, the normative literature on brain drain is incomprehensible without the assumption that people belong to one nation-state, and that the distribution of goods and opportunities is defined by that nation-state's institutions (Brock, 2009; Oberman, 2013; Sager, 2014). Claims that nation-states can impose emigration restrictions or demand compensation from receiving countries are firmly embedded in the worldview defined by methodological nationalism. Political theorists have argued about the cogency of using the (allegedly) harmful effects of skilled migration as grounds for curtailing migration without adequately addressing the legitimacy of invoking national communities as the correct bearers of rights and responsibilities.

\section{How Methodological Nationalism Misleads Political Theorists}

So far I have claimed (1) that work in the social sciences has shown that methodological nationalism impedes the social scientific study of migration and (2) that political theorists have largely operated within a framework of methodological nationalism. In this section, I show why political theorists should attend to transnational, sub- and supra-state actors and recognize how nation-states are products of their global and regional contexts. The abandonment of methodological nationalism permits a more nuanced understanding of the causes of migration and of the need to establish just institutions regulating migration and its distributional effects. I use the US-Mexico migration system to begin to formulate how transnational and global forces inform a more adequate political theory of migration.

Before doing so, I need to address an important objection: even if we agree that social scientists should avoid treating the nation-state as a natural or pre-reflective posit and that political theorists have largely accepted methodological nationalism, how does this affect political theory? The first objection comes from an approach to political theory that seeks

(C) 2014 The Author. Political Studies (C) 2014 Political Studies Association POLITICAL STUDIES: 2014 
to clarify normative principles and concepts independently of facts. From this perspective, the role of normative theorists is to articulate the rights relevant to migration controls, analyze principles of justice and their scope, and justify the weight that should be given to the interests of different agents. Some political theorists believe that they can make substantial progress without engaging the social sciences. For example, Christopher Wellman and Phillip Cole explicitly reject the need to '[furnish] detailed arguments about economic facts and possible consequences' because 'the argument is about rights, the state's right to control membership versus the individual right of freedom of international movement' (Wellman and Cole, 2011, pp. 7-8).

Wellman and Cole underestimate the importance of economic and other facts for arguments about rights. The analysis and criticism of institutions for their causal effects on individuals and groups is a central task of political theory, and political theorists regularly presuppose background facts about the state, its capacities and causal effects (Blake, 2012b). Institutions promote and restrict people's freedom and well-being through coercion and facilitate the distribution of goods. How the social sciences frame issues and social scientists' conclusions about the causal impact of policies and practices matter for political theory, even if empirical assumptions go largely unstated (Sager, 2012). Only normative theorists who are prepared to engage the social scientific literature can satisfactorily address the following questions:

(1) Who/what are the relevant agents and victims (keeping in mind that agents and victims may be collectives)?

(2) How should we conceive agents such as corporations, nongovernmental organizations and transnational communities that operate across multiple legal jurisdictions?

(3) What are the causes of migration? Who causes what and how? How do agents causing migration flows exercise power, and when do power relations lead to domination or exploitation?

(4) What are the correct levels of analysis? Is macro-level political economy the right level for understanding migration, or do we also need to turn to meso-level reflection on networks or families and/or micro-level reflection on individuals and families?

(5) How is migration structured by gender, race, social class and other categories?

(6) What time frame is relevant for analysis? Can theories of migration explain migration flows without incorporating history? Can we talk about spatially distributed opportunities without understanding how past causal chains led to their current distribution?

Our answers to these questions will affect our conclusions about rights and obligations and about the correct principles of distribution and the scope of justice. As mentioned above, Wellman's conviction that freedom of association grounds a broad right to exclude foreigners cannot be assessed until we have determined the relevant associations. More fundamentally, the structure of a right to freedom of association - its claims, liberties, powers and immunities - depends on the type of association, its organization and its purposes. Since morally relevant associations may not cluster within the border of a state, facts have implications for political theory. 
Cole's strategy of analyzing the centrality of freedom of movement to the liberal tradition and showing the inconsistency of not extending this freedom across borders may seem less vulnerable to empirical challenge. Nonetheless, he needs to rely on empirical analysis to show that there is no morally significant difference between prohibiting immigration and prohibiting emigration. Much of his case rests on his refuting arguments that attempt to justify restrictions to migration. An understanding of the nature and purposes of the agents claiming to have a right to curtail migration is necessary to vindicate his position.

Similar points apply when we try to determine a fair distribution across borders. For example, consider Ryan Pevnick's argument that collective property rights can be mobilized to restrict immigration. An entitlement to property and the cluster of rights that determine how it can be acquired, distributed and used depend on many facts, such as how the goods and services are generated, the function of property rights in sustaining them, and how laws and policies correct market failures, boost efficiency and mitigate inequities. Property regimes are social constructions realized through institutions including coercive states and legal regimes. Normative criticism demands an adequate empirical analysis. There is no straightforward path from empirical theories about property regimes to a normative theory, but until we understand how agents and structures exercise power and shape people's mobility and how this influences opportunities, we are not in a position to declare what property rights are relevant to the regulation of migration.

Attention to the social sciences not only clarifies the commitments of our normative theories; they it may also help reveal how dominant suppositions about migration controls embody an ideology that legitimates oppressive power structures. If migration controls play a role in maintaining exploitative transnational divisions of labor, enforcing gender or racial hierarchies or asymmetrically distributing goods and opportunities, then political theorists should investigate how we might move toward more equitable institutions. The criticism of methodological nationalism becomes a plank in a critical theory that aims to reveal how theoretical presuppositions can be grounded in forms of domination, oppression and exploitation.

A second objection to my claim that political theories of migration are tainted by methodological nationalism admits the potential relevance of research in the social sciences, but denies that the focus on states and borders is tainted by methodological nationalism. There are cosmopolitan and state- (or nation-) centered objections to the charge of methodological nationalism. Proponents of open borders (or more open borders) might deny the charge of methodological nationalism on the grounds that they challenge the legitimacy of coercive border controls. Theorists of open borders see themselves as recognizing the arbitrariness of states' use of violence to prevent migration.

This retort overlooks the extent to which proponents of open borders presuppose the nation-state as the target of their objections. Joseph Carens' liberal egalitarian arguments for open borders operate against a background of fixed nation-states (Carens, 2013), as does Veit Bader's contextualized plea for fairly open borders (Bader, 2005) and Gillian Brock's attempt to prescribe win-win migration policies from a cosmopolitan perspective (Brock, 2009). Even Arash Abizadeh's radical challenge to unilateral border controls on the grounds that the demos is in principle unbounded maintains a sharp dichotomy between natives

(C) 2014 The Author. Political Studies (C) 2014 Political Studies Association POLITICAL STUDIES: 2014 
who are members of the community and foreigners who deserve to have coercive border controls justified to them (Abizadeh, 2008). The failure to theorize the nation-state or to 8 challenge its cogency as the principal institution for normative theories of migration has contributed to too much attention being paid to contentious arguments about open versus closed border and not enough to questions about how migration policies structure opportunity sets for distinct populations that cut across national borders.

In contrast, nationalist retorts to the charge of methodological nationalism deny that their privileging of a national or state-based perspective is an error. Political theorists such as Michael Blake and David Miller have developed sophisticated arguments that justify privileging national communities or fellow citizens over foreigners (Blake, 2013; Miller, 2005; 2007). Blake and Miller defend the nation-state on the grounds that state boundaries have moral salience for political theories of migration. Miller's arguments rest on a conception of the nation composed of people who share a common identity and public culture, view their nation as intrinsically valuable, recognize special responsibilities to co-nationals and aspire to some degree of self-determination (Miller, 2007, pp. 124-6). Blake, in contrast, sees states as territorial bounded legal communities with special moral status due to the coercive nature of these legal institutions. In particular, the members of a state can exclude some would-be immigrants because their admission would impose obligations on the current inhabitants that they can rightly reject (Blake, 2013).

My approach will not be to directly challenge their rationales for the granting nations or states special status, but to show how their approaches rely on problematic assumptions about the state grounded in the methodological nationalist paradigm. Miller and Blake's arguments are contingent on empirical claims about the nature of nations and states. Miller's definition of a nation and Blake's conception of a juridical community do not necessarily coincide with the boundaries of the nation-state. If people draw their common identity from supranational groups or if effective coercive legal institutions transcend the boundaries of the nation-state, then Miller and Blake must shift the boundaries of justice.

I focus on US-Mexican migration flows to illustrate the value of a transnational perspective situated within the context of global capitalism. According to the 2010 US Census, 31.8 million Hispanics of Mexican origin live in the United States with 11.7 million of these people born in Mexico. In 2010, the Pew Research Center estimated approximately 11.2 million unauthorized Mexicans in the US, and the World Bank reported approximately US $\$ 22$ billion in remittances from Mexico to the US. Many people of Mexican origin retain connections with families and communities in Mexico and regularly cross between the two countries. Substantial transnational communities straddle the border.

We need to identify agents, levels of analysis, structures, causal relations and historical trajectories relevant to a moral analysis of US-Mexican migration. Methodological nationalists see the US and Mexico as separate containers with Mexican migration a product of exogenous forces driving poor Mexicans responding to limited opportunities at home and comparatively lucrative jobs in the US. A more fruitful approach is to analyze migration from Mexico to the US as a migration system (Massey et al., 2002). In terms of agents, the US and Mexican federal governments and their policies are important, but their role should not lead us to ignore how migration is influenced at the macro-level by the North 
American Free Trade Agreement (NAFTA) and at the meso-level by transnational corporations, subnational communities and nongovernmental organizations.

How does the US-Mexican border 'constitute a visible expression of a profoundly unequal distribution of spatially-differentiated opportunities'? (Ypi, 2008, p. 395) The difference between Nogales, Arizona and Nogales, Sonora can be partly attributed to better institutions in Arizona and the border patrol enforcing laws that maintain the spatialdifferentiation of opportunities (Acemoglu and Robinson, 2012), but this explanation is incomplete. National institutions do not arise and are not sustained in a vacuum, but rather develop as components within and encompassing global, transnational and national systems.

At the macro-level, NAFTA plays a major role in drawing together the US and Mexico. NAFTA is a regional response to shifts in global capitalism that have opened markets to capital flows, deregulation, privatization and the elimination of publically provided social services. These changes have predictably uprooted large segments of the Mexican population unable to compete with mechanized agriculture and the importation of subsidized US crops. The maquiladoras in Northern Mexico, rather than spurring regional development, are largely independent of the larger Mexican economy and are better understood as appendages to American firms seeking a reliable, cheap workforce. The role of border controls in maintaining cheap labor in Mexico and disciplining workers of Mexican origin in the US is not coincidental, but rather serves to reinforce asymmetrical wages and opportunities (Delgado Wise and Marquez Covarrubias, 2008).

Methodological nationalism encourages the homogenization of populations, drawing on nation-building projects' myth of equal citizenship. It is indifferent to internal differences of class, gender and ethnicity that decisively affect people's lives. The fact that people are of Mexican origin does not adequately explain their opportunities or wealth, but only gestures at a broad correlation not sustained by finer grained analysis. The US-Mexican border is a minor inconvenience for Jorge Castañada and Carlos Slim, but a potentially mortal obstacle for workers unable to secure legal documents to cross. Mexicans in the US include undocumented workers, family-class immigrants, women and men with management positions in large corporations and the children of Mexican elites. US immigration law's encouragement of family immigration opens a legal path to residence for millions of Mexicans. Many of these are transnational migrants who shape distributions back in Mexico so that individuals' positions within migration networks in that country play a major role in their opportunities. Towns with a large number of people in the US sending back money have advantages other towns do not, reinforced by government policies such as the $3 \times 1$ Program for Migrants that encourage the investment of remittances. Notably, the failure to target poorer communities combined with political corruption may perpetuate inequalities (Aparicio and Meseguer, 2012).

Categories such as class, race and gender structure policies and the distribution of goods and opportunities. Selective border enforcement and temporary migration patterns reinforce relationships of domination and subordination. Migrants are affected by their position in Mexico's class hierarchies and their place in transnational networks. Gender roles are also significant since decisions often take place within patriarchal families and economic sectors in both countries allocate work along gender lines (Hondagneu-Sotelo, 2003). Within the US, racialized hierarchies based on (presumed) national origin segregate large parts of the

(C) 2014 The Author. Political Studies (C) 2014 Political Studies Association POLITICAL STUDIES: 2014 
Hispanic population in marginal sectors. Class, gender and racial structures affect not only individual experiences where people are pressured to conform to subordinate roles, but also affect policies that shape migration (Johnson, 2009).

Finally, migration from Mexico has a long, historical trajectory. We should not forget that much of the US was once Mexican territory and its acquisition after the MexicanAmerican War also meant the acquisition of a new population. This history includes the importation of Mexican labor facilitated by recruiters to build the railways in response to restrictions of Asian migration and for highly exploitative work in agriculture (Massey et al., 2002). In the mid-twentieth century, the Bracero program formalized labor recruitment, leaving a structural legacy between the US and Mexican economies. Mexico has been subjected to a subordinate relationship with the US since the mid-nineteenth century and labor migration has been a facet of this relationship. Cheap labor has been systematically exploited through recruitment and human beings have been disciplined in the US market by harsh and arbitrary migration policies, including mass deportation (Hing, 2009).

The idea that Mexico and the US are isolated containers or self-contained systems does not sustain reflection. Mexico and the US constitute a transnational economic and social system. Borders do not separate the two countries, but rather enforce international and internal divisions of labor through maquiladoras producing exports and undocumented workers performing labor in peripheral sectors. Coercion at the border does not simply exclude people, but also upholds and shapes institutions in both countries. Much of this is accomplished through the transnational migration industry that has grown up between Mexico and the US. This industry ranges from informal recruiters finding workers for 'the United States' H2A and H2B temporary visa programs' (Hernández León, 2012b, p. 30) to private contractors lobbying for and receiving billions of dollars for border security (Gammeltoft-Hansen, 2012; Hernández_León, 2012b, p. 39) and multinational corpora- [10 tions such as G4S shaping US legislation to support the incarceration of immigrants in their private prisons (Fang, 2013).

What are the implications for political theorists attempting to make sense of migration between Mexico and the US? The current enforcement regime of deportation, detention and border militarization needs to be understood in its broader context. By no means does this imply that the individual rights of members of minority communities and unauthorized migrants are unimportant, but we should not limit our analysis to questions about the justice of domestic authorities using coercion against minorities and foreigners. The methodological nationalist paradigm ignores how the actions of nation-states are restrained by their role in global and regional economic systems. Even the US is not capable of closing its borders because of its adherence to international legal and economic norms. Migration networks have followed structural changes in the world economy to sustain flows through sophisticated smuggling operations, the migration industry, corporate lobbyists and political activism. Remittances are a major part of economic globalization, serving as an explicitly transnational strategy for individuals and as an excuse for the Mexican government to neglect to reform domestic institutions.

Moreover, the domestic labor market cannot be analyzed independently of international labor flows to the secondary sector. Mexican workers in the US are not a puzzling anomaly that the latter has failed to regulate, but rather a product of over a century of state 
recruitment and state sanctioned structural dependence. Mexicans and Mexican Americans, many with ongoing transnational ties, are a major part of the country's community and economy. To conceive of the American economy without transnational migratory ties to Mexico is to imagine a very different world.

The Mexican case cannot be generalized to migration flows around the world without further argument, but it provides vital insights for political theorists who need to expand the set of relevant agents when thinking about distributions. Migration networks lead to unequal distributions that cannot be understood solely through a methodological nationalist paradigm. The nation-state, of course, has a major role in mediating these inequalities, but it is not monolithic and it is by no means clear that the right level of addressing injustice is the state. Moreover, state actions themselves cannot be explained in isolation from forces not captured within its boundaries.

Questions of justice in migration cannot be answered by solely focusing on either receiving or sending states. We need to look at sending and receiving (and transit) states simultaneously and to expand our moral taxonomies. Political theorists should ask how the practices of border enforcement in one region harm families and communities around the world and to what extent these deported migrants are reacting to changes in their opportunity sets affected by actors (including supranational actors) outside of their region. They should inquire into how migration systems are sustained and revive class-based analyses of transnational divisions of labor. They must acknowledge how migration and development are unavoidably intertwined and how development invariably causes migration (and thus abandon naive trade-offs between more open borders and development aid). They should ask how corporations are implicated in initiating migration and sustaining migration flows (in part by influencing political processes) and determine their moral responsibilities (Hernández León, 2012a).

More generally, political theorists should turn to questions of power, causality and responsibility (Schiller, 2005). Insofar as the effects of migration are morally problematic or [1] undesirable, what triggers them? How are the environments of sending and receiving areas structured and who is morally responsible for these structures? The move beyond methodological nationalism promises a more nuanced understanding of migration and its moral implications. Political theorists may discover that border controls have a deeply objectionable role not only in limiting people's opportunities, but in upholding oppressive class, gender and political relationships. Analysis will often include multiple agents, many of whom are located in dispersed geographical regions, but nonetheless promote their interests from abroad. This will allow normative theorists to move toward an analysis of the movement of people and its effects adequate for a world increasingly constituted by global, transnational and regional dynamics.

(Accepted: 3 July 2014)

\footnotetext{
About the Author

Alex Sager is Assistant Professor of Philosophy and University Studies at Portland State University. His main research program is in applied political philosophy on topics surrounding migration. Alex Sager, Department of Philosophy, Portland State University, Neuberger Hall 393, 724 SW Harrison, Portland, OR 97201, USA; email: asager@pdx.edu

C 2014 The Author. Political Studies (C) 2014 Political Studies Association POLITICAL STUDIES: 2014
} 


\section{References}

Acemoglu, D. and Robinson, J. A. (2012) Why Nations Fail: The Origins of Power, Prosperity and Poverty. New York: Crown. (mina, A., Nergiz, D. D., Faist, T. and Glick Schiller, N. (2012) Beyond Methodological Nationalism: Research Methodologies 2 , Cross-Border Studies. New York: Routledge.

Anderson, B. (2006) Imagined Communities: Reflections on the Origin and Spread of Nationalism, revised edition. London: Verso. Aparicio, F. J. and Meseguer, C. (2012) 'Collective Remittances and the State: The 3x1 Program in Mexican Municipalities', World Development, 40 (1), 206-22.

Attas, D. (2000) 'The Case of Guest Workers: Exploitation, Citizenship and Economic Rights', Res Publica, 6 (1), 73-92.

Bader, V. (2005) 'The Ethics of Immigration', Constellations, 12 (3), 331-61.

Barry, B. (2002) Culture and Equality. Cambridge, MA: Harvard University Press.

Basch, L., Glick-Schiller, N. and Szanton Blanc, C. (1994) Nations Unbound: Transnational Projects, Post-Colonial Predicaments and Deterritorialized Nation-States. New York: Gordon \& Breach.

Bauböck, R. (2003) 'Towards a Political Theory of Migrant Transnationalism', International Migration Review, 37 (3), $700-23$.

Bauböck, R. (2011) 'Temporary Migrants, Partial Citizenship and Hypermigration', Critical Review of International Social and Political Philosophy, 14 (5), 665-93.

Beck, U. (2000) What is Globalization? Malden, MA: Polity Press.

Bell, D. A. and Piper, N. (2005) 'Justice for Migrant Workers? The Case of Foreign Domestic Workers in Hong Kong and Singapore', in W. Kymlicka and B. He (eds), Multiculturalism in Asia. New York: Oxford University Press, pp. 196-222.

Blake, M. (2012a) 'Global Distributive Justice: Why Political Philosophy Needs Political Science', Annual Review of Political Science, 15, 121-36.

Blake, M. (2012b) 'Immigration, Association and Antidiscrimination', Ethics, 122 (4), 748-62.

Blake, M. (2013) 'Immigration, Jurisdiction and Exclusion', Philosophy and Public Affairs, 41 (2), 103-30.

Bloemraad, I., Korteweg, A. and Yurdakul, G. (2008) 'Citizenship and Immigration: Multiculturalism, Assimilation and Challenges to the Nation-State', Annual Review of Sociology, 34, 153-79.

Borjas, G. J. (2001) Heaven's Door: Immigration Policy and the American Economy. Princeton, NJ: Princeton University Press. Brock, G. (2009) Global Justice: A Cosmopolitan Account. New York: Oxford University Press.

Carens, J. (2013) The Ethics of Immigration. New York: Oxford University Press.

Cavallero, E. (2006) 'An Immigration-Pressure Model of Global Distributive Justice', Politics, Philosophy and Economics, 5 (1), 97-127.

Chernilo, D. (2006) 'Social Theory's Methodological Nationalism: Myth and Reality', European Journal of Social Theory, 9 (1), 5-22.

De Haas, H. (2010) 'Migration and Development: A Theoretical Perspective', International Migration Review, 44 (1), 1-38.

Delgado Wise, R. and Marquez Covarrubias, H. (2008) 'The Mexico-United States Migratory System: Dilemmas of Regional Integration, Development and Emigration', in S. Castles and R. Delgado Wise (eds), Migration and Development: Perspectives from the South. Geneva: International Organization for Migration, pp. 113-42.

Fang, L. (2013) 'How Private Prisons Game the Immigration System', The Nation, 27 February. Available from: http:// www.thenation.com/article/173120/how-private-prisons-game-immigration-system\#axzz2ajTXoEy0 [Accessed 6 June 2014].

Fine, S. (2010) 'Freedom of Association is Not the Answer', Ethics, 120 (2), 338-56.

Gammeltoft-Hansen, T. (2012) 'The Rise of the Private Border Guard: Governance and Accountability in the Involvement of Non-State Actors in Migration Management', in T. Gammeltoft-Hansen and N. Sorensen (eds), The Migration Industry and the Commercialization of International Migration. New York: Routledge, pp. 128-51.

Gammeltoft-Hansen, T. and Nyberg Sorensen, N. (2012) The Migration Industry and the Commercialization of International Migration. New York: Routledge.

Glick Schiller, N. (2010) 'A Global Perspective on Transnational Migration: Theorizing Migration without Methodological Nationalism', in R. Bauböck and T. Faist (eds), Diaspora and Transnationalism: Concepts, Theories and Methods. Amsterdam: Amsterdam University Press, pp. 109-29.

Glick Schiller, N. (2012) ‘Migration and Development without Methodological Nationalism', in P. Gardiner Barber and W. Lem (eds), Migration in the 21st Century: Political Economy and Ethnography. New York: Routledge, pp. 38-63.

Glick Schiller, N. and Faist, T. (2010) Migration, Development and Transnationalism: A Critical Stance. New York: Berghahn Books.

Hernández León, R. (2012a) 'La industria de la migración en el sistema migratorio México-Estados Unidos', Trace, 60, $41-61$.

Hernández León, R. (2012b) 'Conceptualizing the Migration Industry', in T. Gammeltoft-Hansen and N. Sorensen (eds), The Migration Industry and the Commercialization of International Migration. New York: Routledge, pp. 24-44.

Hidalgo, J. S. (2014) 'Freedom, Immigration and Adequate Options', Critical Review of International Social and Political Philosophy, 17 (2), 212-34.

Hing, B. O. (2009) 'Institutional Racism, ICE Raids and Immigration Reform', University of San Francisco Law Review, 44 (1), 1-49.

Hondagneu-Sotelo, P. (ed.) (2003) Gender and US Immigration: Contemporary Trends. Berkeley, CA: University of California Press. 
Huntington, S. (2005) Who are We? The Challenge to America's National Identity. New York: Simon \& Schulster.

International Institute for Democracy and Electoral Assistance (IDEA) (2005) Electoral System Design: The New International IDEA Handbook. Stockholm: IDEA.

Johnson, K. R. (2009) 'The Intersection of Race and Class in US Immigration Law and Enforcement', Law and Contemporary Problems, 72 (1), 1-35.

Joppke, C. and Morawska, E. (eds) (2002) Toward Assimilation and Citizenship: Immigrants in Liberal Nations. Basingstoke: Palgrave Macmillan.

Kapur, D. and McHale, J. (2005) Give Us Your Best and Brightest: The Global Hunt for Talent and Its Impact on the Developing World. Washington, DC: Center for Global Development.

King, R., Skeldon, R. and Vullnetari, J. (2008) 'Internal and International Migration-Bridging the Theoretical Divide', Working Paper 52. Brighton: Sussex Centre for Migration Research, University of Sussex.

Kymlicka, W. (2001) 'Territorial Boundaries: A Liberal Egalitarian Perspective', in D. Miller and S. H. Hashmi (eds), Boundaries and Justice: Diverse Ethical Perspectives. Princeton, NJ: Princeton University Press, pp. 249-75.

Lemberg-Pedersen, M. (2012) 'Private Security Companies and the European Borderscapes', in T. Gammeltoft-Hansen and N. Sorensen (eds), The Migration Industry and the Commercialization of International Migration. New York: Routledge, pp. 152-69.

Lenard, P. T. (2010) 'Culture, Free Movement and Open Borders', Review of Politics, 72 (4), 627-52.

Lenard, P. T. and Straehle, C. (2011) 'Temporary Labour Migration, Global Redistribution and Democratic Justice', Politics, Philosophy and Economics, 11 (2), 206-30.

Levitt, P. (1998) 'Social Remittances: Migration Driven Local-Level Forms of Cultural Diffusion', International Migration Review, 32 (4), 926-48.

Levitt, P. and Jaworsky, B. N. (2007) 'Transnational Migration Studies: Past Developments and Future Trends', Annual Review of Sociology, 33, 129-56.

Levitt, P. and Schiller, N. G. (2006) 'Conceptualizing Simultaneity: A Transnational Social Field Perspective on Society', International Migration Review, 38 (3), 1002-39.

Lister, M. (2012) 'Who are Refugees?', Law and Philosophy, 32 (5), 645-71.

Massey, D., Durand, J. and Malone, N. (2002) Beyond Smoke and Mirrors: Mexican Immigration in an Era of Economic Integration. New York: Russell Sage Foundation.

Massey, D. G., Arango, J., Hugo, G., Kouaouci, A., Pellegrino, A. and Taylor, J. E. (1998) Worlds in Motion: Understanding International Migration at the End of the Millennium. Oxford: Clarendon Press.

Miller, D. (2000) Citizenship and National Identity. Cambridge, MA: Polity.

Miller, D. (2005) 'Immigration: The Case for Limits', in A. Cohen and C. H. Wellman (eds), Contemporary Debates in Applied Ethics. Malden, MA: Blackwell, pp. 193-206.

Miller, D. (2007) National Responsibility and Global Justice. New York: Oxford University Press.

Miller, D. (2008) 'Immigrants, Nations and Citizenship', Journal of Political Philosophy, 16 (4), 371-90.

Miller, R. W. (2010) Globatizing Justice: The Ethies of Poverty Power. New York: Oxford University Press.

Oberman, K. (2013) 'Can Brain Drain Justify Immigration Restrictions?', Ethics, 123 (3), 427-55.

Owen, D. (2012) 'Constituting the Polity, Constituting the Demos: On the Place of the All Affected Interests Principle in Democratic Theory and in Resolving the Democratic Boundary Problem', Ethics and Global Politics, 5 (3), $129-52$.

Pevnick, R. (2011) Immigration and the Constraints of Justice: Between Open Borders and Absolute Sovereignty. New York: Cambridge University Press.

Piore, M. J. (1980) Birds of Passage: Migrant Labor and Industrial Societies. New York: Cambridge University Press.

Pogge, T. (2006) 'Migration and Poverty', in R. E. Goodin and T. Pettit (eds), Contemporary Political Philosophy: An Anthology, second edition. Oxford: Blackwell, pp. 710-20.

Portes, A. (2003) 'Conclusion: Theoretical Convergencies and Empirical Evidence in the Study of Immigrant Transnationalism', International Migration Review, 37 (3), 874-92.

Portes, A. and Bach, R. L. (1985) Latin Journey: Cuban and Mexican Immigrants in the United States. Berkeley, CA: University of California Press.

Rawls, J. (2002) The Law of Peoples. Cambridge, MA: Harvard University Press.

Robinson, W. I. (2001) 'Social Theory and Globalization: The Rise of a Transnational State', Theory and Society, 30 (2), $157-200$

Sager, A. (2012) 'The Implications of Migration Theory for Distributive Justice', Global Justice, 5, 56-70.

Sager, A. (2014) 'Reframing the Brain Drain', Critical Review of International Social and Political Philosophy, 17 (5), $560-79$.

Salazar Parreñas, R. (2008) The Force of Domesticity: Filipina Migrants and Globalization. New York: New York University Press.

Sassen, S. (1988) The Mobility of Labor and Capital: A Study in International Investment and Labor Flow. New York: Cambridge University Press.

Sassen, S. (2002) 'Global Cities and Survival Circuits', in B. Ehrenreich and A. Russell Hochschild (eds), Global Woman. New York: Henry Holt, pp. 254-74.

Schiller, G. (2005) 'Transnational Social Fields and Imperialism: Bringing a Theory of Power to Transnational Studies', Anthropological Theory, 5 (4), 439-61.

Shachar, A. (2009) The Birthright Lottery: Citizenship and Global Inequality. Cambridge, MA: Harvard University Press.

Smith, A. D. (1983) 'Nationalism and Classical Social Theory', British Journal of Sociology, 34 (1), 19-38.

C 2014 The Author. Political Studies (C) 2014 Political Studies Association

POLITICAL STUDIES: 2014 
Sorensen, N. N. (2012)'Pevisiting the Migration Development Nexus: From Social Networks and Remittances to Markets for Migration Control', Interat Migation, 50 (3), 6176.

Stark, O. (1991) The Migration of Labor. Cambridge, MA: Basil Blackwell.

United Nations Development Programme (UNDP) (2009) Human Development Report, 2009: Overcoming Barriers - Human Mobility and Development. New York: Palgrave Macmillan.

Waldron, J. (1992) 'Minority Cultures and the Cosmopolitan Alternative', University of Michigan Journal of Law Reform, 25, 751-93.

Wallerstein, I. (1974) The Modern World-System: Capitalist Agriculture and the Origins of the European World-Economy in the Sixteenth Century. New York: Academic Press.

Walzer, M. (1983) Spheres of Justice. New York: Basic Books.

Wellman, C. H. and Cole, P. (2011) Debating the Ethics of Immigration: Is There a Right to Exclude? Oxford: Oxford University Press.

Wimmer, A. and Glick Schiller, N. (2002) 'Methodological Nationalism and beyond: Nation-State Building, Migration and the Social Sciences', Global Networks, 2 (4), 301-34.

Wimmer, A. and Glick Schiller, N. (2003) 'Methodological Nationalism, the Social Sciences and the Study of Migration: An Essay in Historical Epistemology', International Migration Review, 37 (3), 576-610.

Wolf, E. R. (1982) Europe and the People without History. Berkeley, CA: University of California Press.

Ypi, L. (2008) 'Justice in Migration: A Closed Borders Utopia?', Journal of Political Philosophy, 16 (4), $391-418$.

Zhou, M. (200@) 'Revisiting Ethnic Entrepreneurship: Convergencies, Controversies and Conceptual Advancements', International Migration Review, 38 (3), 1040-74.

Zolberg, A. (1987) 'Wanted But Not Welcome: Alien Labor in Western Development', in W. Alonso (ed.), Population in an Interacting World. Cambridge, MA: Harvard University Press, pp. 36-73. 


\section{AUTHOR QUERY FORM}

\section{Dear Author,}

During the preparation of your manuscript for publication, the questions listed below have arisen. Please attend to these matters and return this form with your proof.

Many thanks for your assistance.

\begin{tabular}{|c|c|c|}
\hline $\begin{array}{l}\text { Query } \\
\text { References }\end{array}$ & Query & Remarks \\
\hline 1 & $\begin{array}{l}\text { AUTHOR: Chernilo, } 2007 \text { has been changed to Chernilo, } \\
2006 \text { so that this citation matches the Reference List. Please } \\
\text { confirm that this is correct. }\end{array}$ & \\
\hline 2 & $\begin{array}{l}\text { AUTHOR: Levitt and Glick Schiller, } 2006 \text { has been changed to } \\
\text { Levitt and Schiller, } 2006 \text { so that this citation matches the Ref- } \\
\text { erence List. Please confirm that this is correct. }\end{array}$ & \\
\hline 3 & $\begin{array}{l}\text { AUTHOR: Zhou, } 2004 \text { has been changed to Zhou, } 2006 \text { so } \\
\text { that this citation matches the Reference List. Please confirm that } \\
\text { this is correct. }\end{array}$ & \\
\hline 4 & $\begin{array}{l}\text { AUTHOR: Lemberg-Petersen, } 2012 \text { has been changed to } \\
\text { Lemberg-Pedersen, } 2012 \text { so that this citation matches the Ref- } \\
\text { erence List. Please confirm that this is correct. }\end{array}$ & \\
\hline 5 & $\begin{array}{l}\text { AUTHOR: Bell and Piper, } 2006 \text { has been changed to Bell and } \\
\text { Piper, } 2005 \text { so that this citation matches the Reference List. } \\
\text { Please confirm that this is correct. }\end{array}$ & \\
\hline 6 & $\begin{array}{l}\text { AUTHOR: Rawls, } 1999 \text { has been changed to Rawls, } 2002 \text { so } \\
\text { that this citation matches the Reference List. Please confirm that } \\
\text { this is correct. }\end{array}$ & \\
\hline 7 & $\begin{array}{l}\text { AUTHOR: Hidalgo, } 2012 \text { has been changed to Hidalgo, } 2014 \\
\text { so that this citation matches the Reference List. Please confirm } \\
\text { that this is correct. }\end{array}$ & \\
\hline 8 & $\begin{array}{l}\text { AUTHOR: Abizadeh, } 2008 \text { has not been included in the Ref- } \\
\text { erence List, please supply full publication details. }\end{array}$ & \\
\hline 9 & $\begin{array}{l}\text { AUTHOR: Hernández-León, } 2012 \text { b has been changed to } \\
\text { Hernández León, 2012b so that this citation matches the Ref- } \\
\text { erence List. Please confirm that this is correct. }\end{array}$ & \\
\hline
\end{tabular}




\begin{tabular}{|l|l|l|}
\hline $\begin{array}{l}\text { Query } \\
\text { References }\end{array}$ & Query & Remarks \\
\hline 10 & $\begin{array}{l}\text { AUTHOR: Hernández-León, 2012b has been changed to } \\
\text { Hernández León, 2012b so that this citation matches the Ref- } \\
\text { erence List. Please confirm that this is correct. }\end{array}$ & \\
\hline 11 & $\begin{array}{l}\text { AUTHOR: Glick Schiller, 2005 has been changed to Schiller, } \\
\text { 2005 so that this citation matches the Reference List. Please } \\
\text { confirm that this is correct. }\end{array}$ & \\
\hline 12 & $\begin{array}{l}\text { AUTHOR: Please check this website address and confirm that } \\
\text { it is correct. (Please note that it is the responsibility of the } \\
\text { author(s) to ensure that all URLs given in this article are correct } \\
\text { and useable.) }\end{array}$ & \\
\hline 13 & $\begin{array}{l}\text { AUTHOR: Miller, 2010 has not been cited in the text. Please } \\
\text { indicate where it should be cited; or delete from the Reference } \\
\text { List. }\end{array}$ & $\begin{array}{l}\text { AUTHOR: Sørensen, 2012 has not been cited in the text. } \\
\text { Please indicate where it should be cited; or delete from the } \\
\text { Reference List. }\end{array}$ \\
\hline 14
\end{tabular}


Required software to e-Annotate PDFs: Adobe Acrobat Professional or Adobe Reader (version 8.0 or above). (Note that this document uses screenshots from Adobe Reader $\mathrm{X}$ )

The latest version of Acrobat Reader can be downloaded for free at: http://get.adobe.com/reader/

Once you have Acrobat Reader open on your computer, click on the Comment tab at the right of the toolbar:

닙

This will open up a panel down the right side of the document. The majority of tools you will use for annotating your proof will be in the Annotations section, pictured opposite. We've picked out some of these tools below:

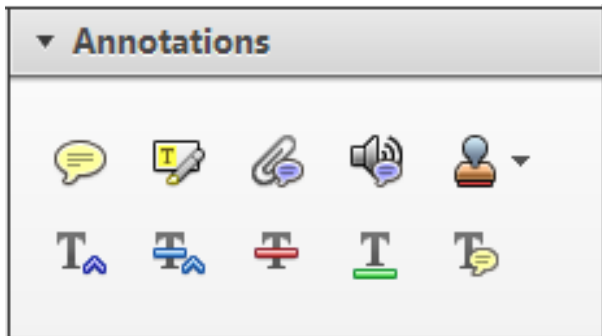

1. Replace (Ins) Tool - for replacing text.

Strikes a line through text and opens up a text box where replacement text can be entered.

\section{How to use it}

- Highlight a word or sentence.

- Click on the Replace (Ins) icon in the Annotations section.

- Type the replacement text into the blue box that appears.

Idard tramework for the analysis of $\mathrm{m}$ icy-Nevertheless, it also led to exog،

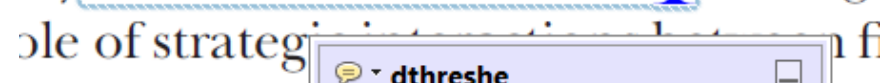
aber of comp 08/06/2011 15:58:17

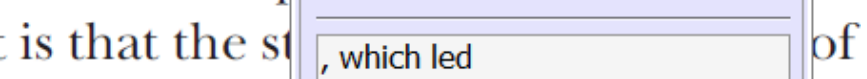
nain compo: be level, are exc nc

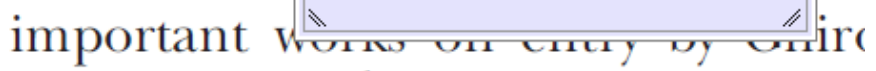
M heneferth) ${ }^{1}$ we anen the 'hlark $\mathrm{h}$

3. Add note to text Tool - for highlighting a section to be changed to bold or italic.

T Highlights text in yellow and opens up a text box where comments can be entered.

\section{How to use it}

- Highlight the relevant section of text.

- Click on the Add note to text icon in the Annotations section.

- Type instruction on what should be changed regarding the text into the yellow box that annears.

namic responses of mark ups ent with the VAR evidence

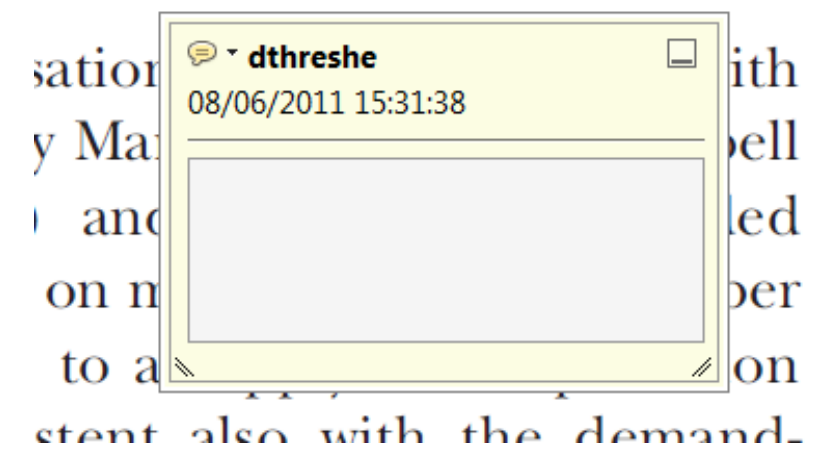

2. Strikethrough (Del) Tool - for deleting text.

Thikes a red line through text that is to be deleted.

\section{How to use it}

- Highlight a word or sentence.

- Click on the Strikethrough (Del) icon in the Annotations section.

there is no room tor extra prohts al c ups are zero and the number of ret) values are not determined by Blanchard and Kiyotaki (1987), rfect competition in general equilil ts of aggregate demand and supply lassical framework assuming monol eon an evorenois number of firms

\section{Add sticky note Tool - for making notes at} specific points in the text.

Marks a point in the proof where a comment needs to be highlighted.

\section{How to use it}

- Click on the Add sticky note icon in the Annotations section.

- Click at the point in the proof where the comment should be inserted.

- Type the comment into the yellow box that appears.

lallu allu suppiy silucks. hivst vi

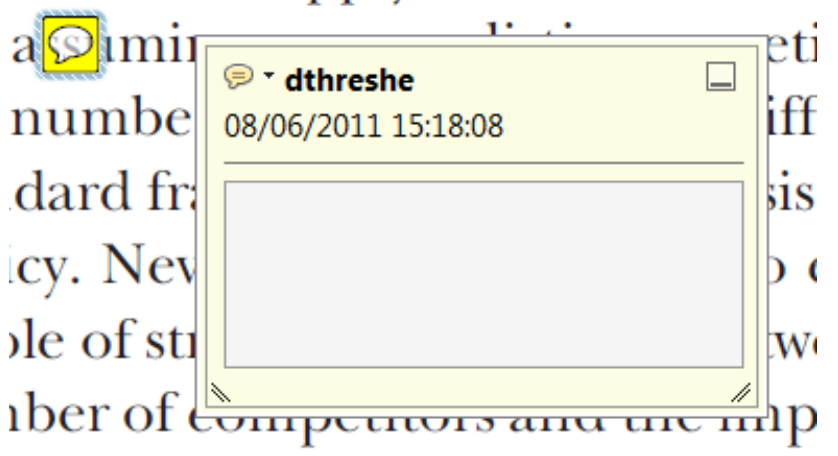

is that the structure of the secto 
5. Attach File Tool - for inserting large amounts of text or replacement figures.

Inserts an icon linking to the attached file in the appropriate pace in the text.

How to use it

- Click on the Attach File icon in the Annotations section.

- Click on the proof to where you'd like the attached file to be linked.

- Select the file to be attached from your computer or network.

- Select the colour and type of icon that will appear in the proof. Click OK.

E N D

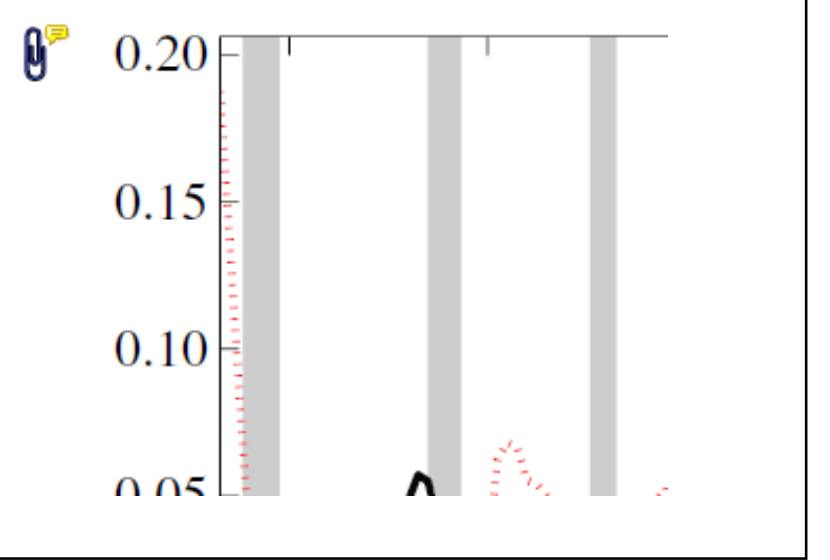

6. Add stamp Tool - for approving a proof if no corrections are required.

- Inserts a selected stamp onto an appropriate place in the proof

\section{How to use it}

- $\quad$ Click on the Add stamp icon in the Annotations section.

- $\quad$ Select the stamp you want to use. (The Approved stamp is usually available directly in the menu that appears).

- Click on the proof where you'd like the stamp to appear. (Where a proof is to be approved as it is, this would normally be on the first page).

of the Dusiness cycie, starting with the on perfect competition, constant ret

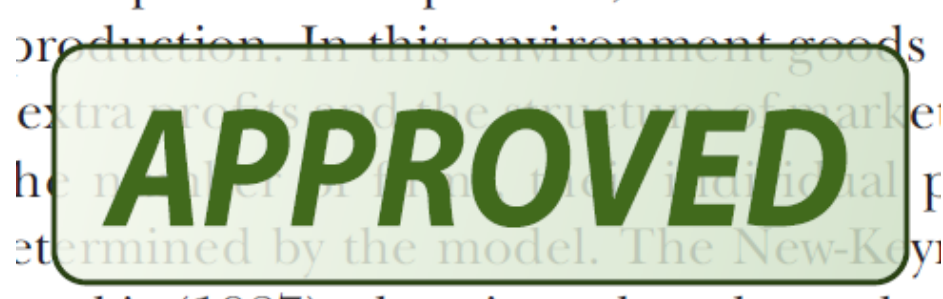

otaki (1987), has introduced produc general equilibrium models with nomin
- Drawing Markups

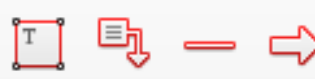

$0 \square \sqrt{6} D$

\section{How to use it}

- Click on one of the shapes in the Drawing Markups section.

- Click on the proof at the relevant point and draw the selected shape with the cursor.

- To add a comment to the drawn shape, move the cursor over the shape until an arrowhead appears.

- Double click on the shape and type any text in the red box that appears.
7. Drawing Markups Tools - for drawing shapes, lines and freeform annotations on proofs and commenting on these marks.

Allows shapes, lines and freeform annotations to be drawn on proofs and for comment to be made on these marks.

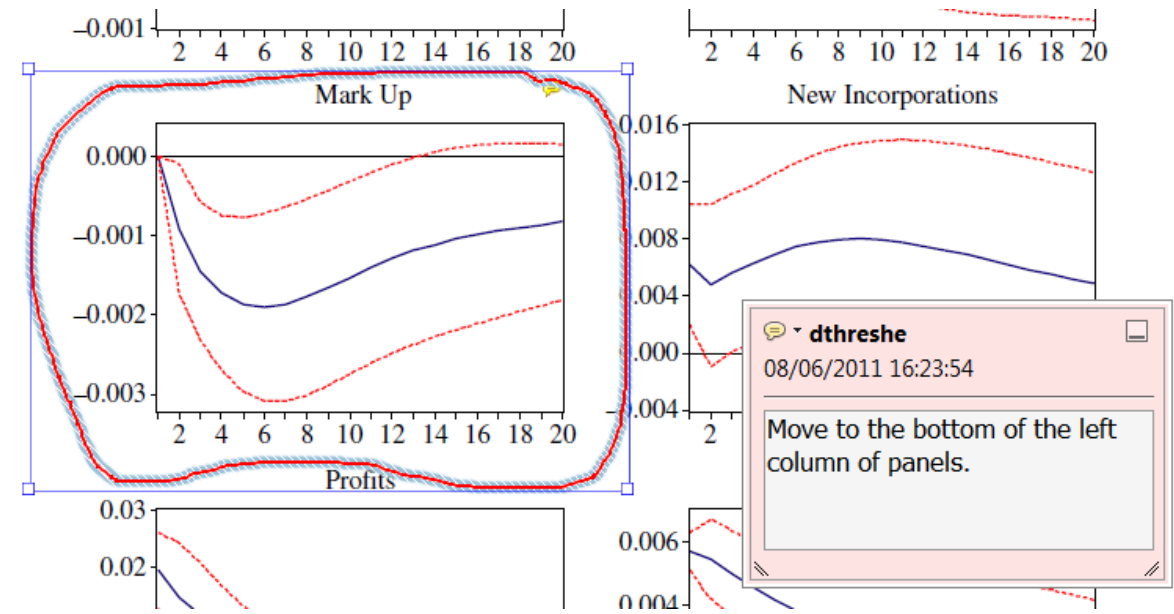

For further information on how to annotate proofs, click on the Help menu to reveal a list of further options:

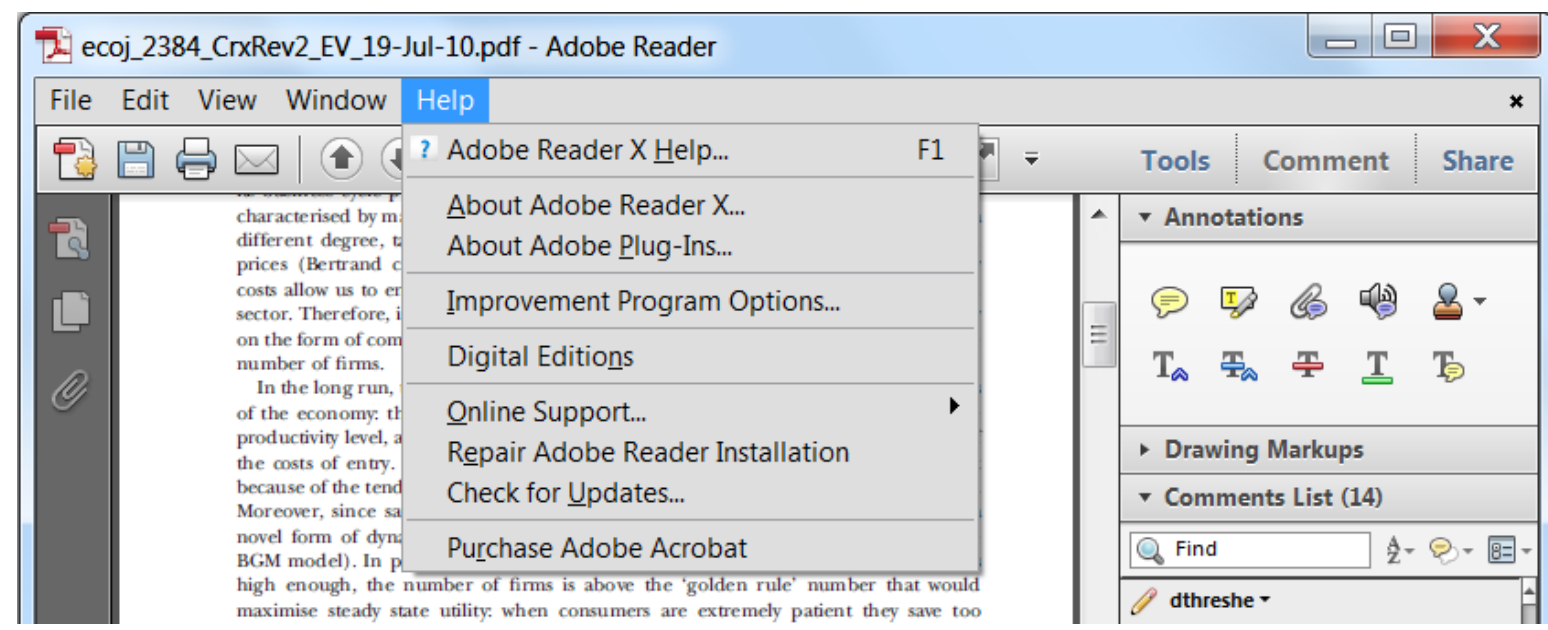

